\title{
BREVE HISTORIA DE UNA FOTOGRAFÍA
}

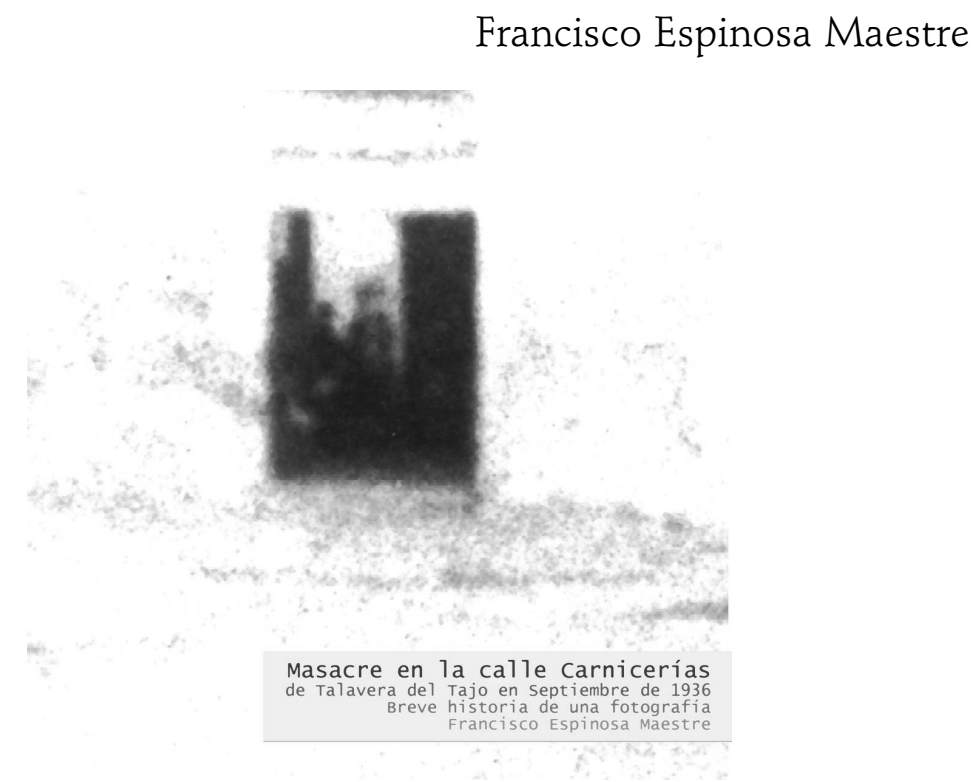

Para Jorge Arévaloํㅗ y María Oliver

\section{BREVE INTRODUCCIÓN}

Es ya un lugar común decir que toda fotografía de carácter histórico debe ser, por principio, objeto de sospecha. No ya sólo por su posible manipulación, caso de algunas imágenes de la guerra civil norteamericana -la famosa Cosecha de muerte de Timothy O'Sullivan, uno de los pioneros de la fotografía bélica y, al mismo tiempo, de la preparación de la realidad: él mismo colocaba a los soldados

1. A Jorge Arévalo debo la paciente tarea de escanear y montar el power-point con los diferentes pasos de la foto y esa fantasmal y sugerente imagen, surgida de aumentar el fondo de la fotografía, con la que se abría y cerraba el montaje. En definitiva, fue él quien descubrió que la persona que camina por la acera derecha no era el único personaje vivo que aparecía allí. 


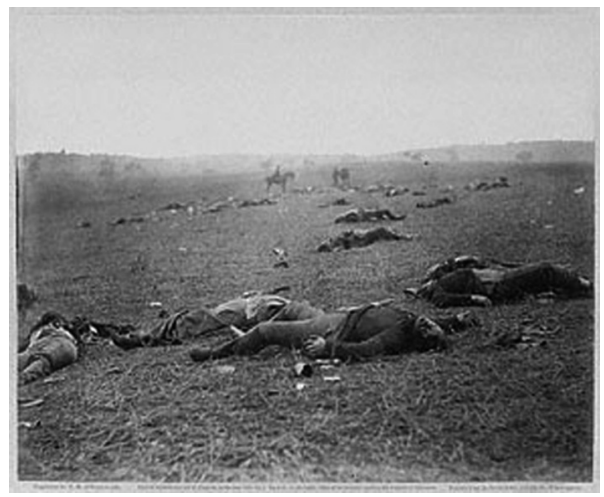

Foto 1


Foto 2 y 3

«muertos» por el campo para que el país conociera la dureza de la guerra (foto 1) - o de las conocidas fotografías de la historia soviética donde van desapareciendo diferentes personajes a medida que van cayendo en desgracia (foto $2 \mathrm{y}$ 3 ), sino porque, aunque reflejen la realidad o pretendan reflejarla, son fruto de un montaje.


Foto 4 y 5 


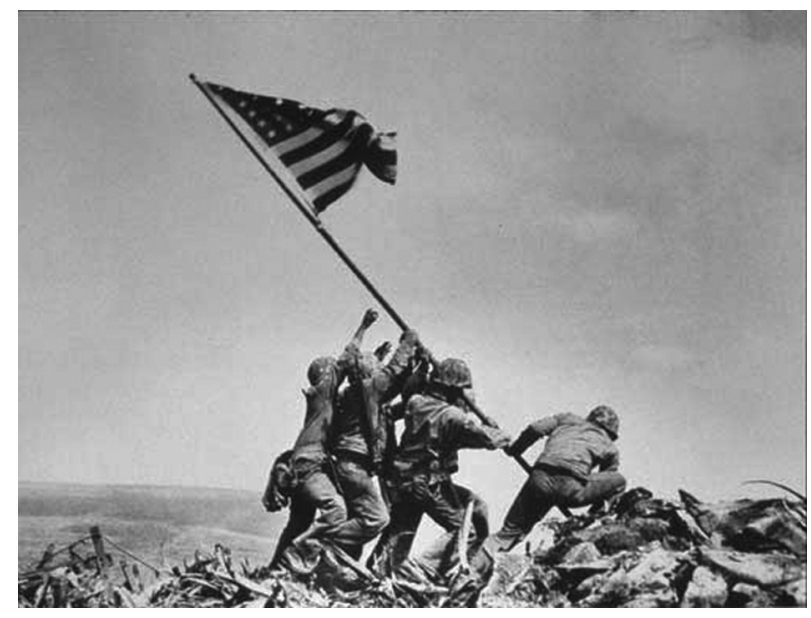

Foto 6

Sería el caso de famosas fotos como la de Yevgeni Khaldey del Reichtag recién ocupado por los soviéticos (fotos 4 y 5) o la de de Joe Rosenthal de la colocación de la bandera yankee en Ivo Jima (foto 6). En el primer caso, para añadir dramatismo a la escena, se puso un fondo de humo y en el segundo, como la toma real no era suficientemente épica, se repitió después de manera adecuada, que es como la conocemos (foto 2 ).

También, aunque hay división de pareceres, de algunas de las fotografías tomadas por Agustí Centelles en las calles de Barcelona el 19 de julio de 1936. Desde luego, en este caso, no se puede dudar de su gran valor testimonial, aunque algunos detalles indican que fueron tomadas cuando ya la lucha había acabado, es decir, con los guardias y milicianos simulando que luchan. De he-

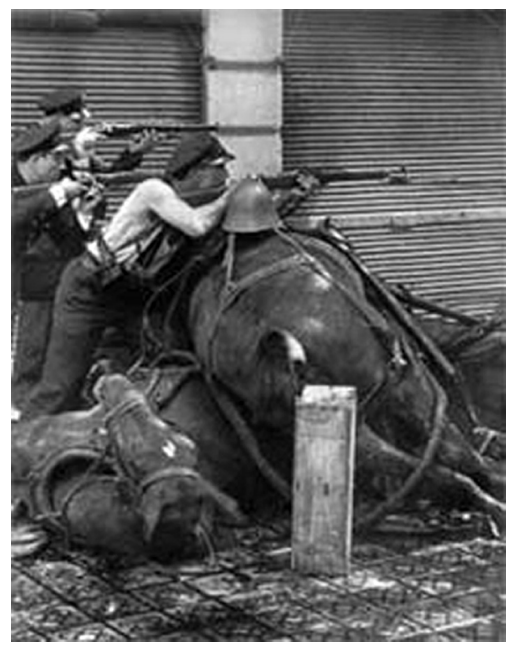

Foto 7 




Foto 8

cho, la foto que muestra a tres hombres disparando sobre unos caballos como parapeto fue estropeada por un sujeto un tanto estrafalario que, enarbolando una pequeña pistola en la mano, se coló en el campo de visión por el lado izquierdo. En la prensa de aquellos días se vio la imagen completa pero hace ya tiempo que el señor de la pistola ha desaparecido de la foto (fotos 7 y 8). Le restaba verosimilitud ${ }^{2}$.

El caso de la fotografía que ahora nos ocupa es diferente. En ella no se ha manipulado la imagen ni se ha hecho otra toma para darle más verismo. Lo que se ha cambiado es el pie de foto. Percibir esto, al contrario que en los casos mencionados, requiere un complicado proceso de observación. Una cosa es descubrir que la foto de Rosenthal fue preparada o sospechar que los carabineros posaron para Centelles y otra muy diferente utilizar una foto que refleja una realidad para decir que refleja lo contrario. Este es el caso de la foto de Juan José Serrano. Darse cuenta del engaño requiere un largo seguimiento y llegar a saber la historia que hay tras ella es casi un milagro. Y ahí radica su singularidad, en saber cuándo y dónde fue tomada, qué había ocurrido dicho día y, sobre todo, en el hecho extraordinario de haber encontrado un testigo del hecho que la imagen plasmaba. El relato que sigue no recoge cronológicamente los pasos que he llegado a conocer de la fotografía sino la manera en que a mí me fue llegando la información sobre ella.

2. La historia de esta foto pudo verse con detalle en la exposición dedicada a Agustí Centelles en el Palacio de la Virreina de la que fue comisario Miquel Berga. Véase el catálogo: Centelles, las vidas de un fotógrafo (1909-1985), Lunwerg/Ayuntamiento de Barcelona, 2006, p. 28 y 44-45. 


\section{PROPAGANDA Y DESINFORMACIÓN EN TORNO A UNA FOTOGRAFÍA (1936-2006)}

Vi por primera vez la foto a comienzos de los 90 , cuando revisaba el fondo Serrano -un importante reportero gráfico cuyo archivo fue adquirido por el Ayuntamiento en los años 80 - de la Hemeroteca Municipal de Sevilla en busca de imágenes para La guerra civil en Huelva, que vería la luz en 1996 (Diputación de Huelva, 2005-4a). Fue entonces cuando me pareció ver por primera vez aquella impresionante fotografía del grupo de cadáveres en la mitad de una calle solitaria por una de cuyas aceras camina un hombre. Y digo que me pareció porque, aunque a mí me hubiera pasado inadvertida, ya la debía de haber visto en alguno de los folletos propagandísticos franquistas que luego mencionaré.



Como su autor era Serrano y se hallaba junto a imágenes relativas a los primeros días del golpe militar en Sevilla y a otras de la ruta hacia Madrid acompañando a la columna de la muerte (Toledo entre otros lugares, por ejemplo), pensé que había sido tomada en algún lugar de la ciudad, en cuyo caso resultaba lógico pensar que se tratase de los cadáveres de los mineros de Huelva asesinados por grupos en diferentes puntos de Sevilla el 31 de agosto de 1936. Como sabía los lugares donde cayeron pensé que, de ser alguno de ellos, debía ser Triana. Junto con mi amigo Manolo Tapada hicimos una especie de encuesta por ese barrio con objeto de reconocer la calle de la foto. Pero como la gente se centraba de inmediato en los cadáveres los tuve que tapar de manera un tanto artesanal, con una franja de papel pintado en tono similar al de calle e hice una fotocopia que fue la que mostré desde entonces (la imagen que se ve a continuación no es evidentemente la de la fotocopia, que no conservo, pero el efecto es el mismo). 
El resultado fue curioso y no deja de ser indicativo de la cautela con la que deben ser tomados los testimonios orales: varias personas aseguraron que se trataba de Triana y una dijo reconocer sin duda alguna y con todo lujo de detalles -hasta los nombres de los vecinos que habitaban en tal o cual casa- una zona ya inexistente de la confluencia de las calles Pagés del Corro y Castilla. Lo cierto es que no hubiera resultado nada extraño que, convertido en acto ejemplarizante el consejo de guerra a los miembros de la columna de Huelva, del cual informó diariamente la prensa, se permitiera a Serrano dejar constancia del hecho.



Por tal motivo, poco después, en 1996, cuando se publicó el libro aludido de Huelva decidí incluir la foto pero, guiado por la cautela, sólamente planteé la posibilidad de que fuese aquel extremo del barrio sevillano y que aquellos hombres fueran algunos de los mineros onubenses asesinados a fines de agosto por su participación en el intento de frustrar el golpe de Queipo el 19 de julio de 1936 y cuya aventura acabó en la zona de acceso a la ciudad conocida por La Pañoleta.

No mucho después me enteré casualmente que la fotografía había aparecido varios años antes en Sevilla fue la clave (Castillejo, Sevilla, 1992), obra del periodista y ex director de la edición sevillana del $A B C$ Nicolás Salas. Allí, en la página 568 del tomo segundo, aparecían tres fotografías demostrativas del terror rojo -ésta entre ellas- con el texto que puede leerse sobre la foto. El autor, aunque probablemente la conocía por uno de los Avances de la Causa General, ocultó el nombre de la localidad donde había ocurrido la masacre y, sin mayor problema, lo presentó como un acto achacable al Frente Popular. Comprobé, además, que no era el único caso en dicho libro en que las fotografías habían si- 


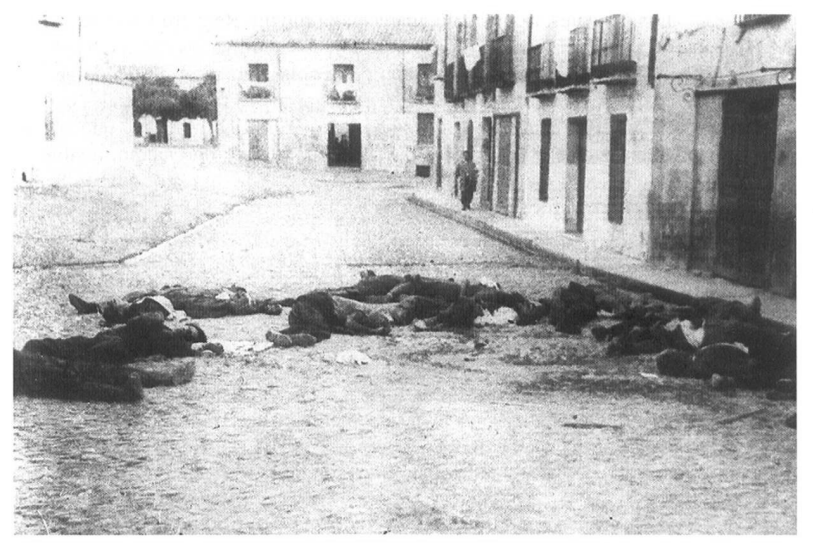

¿Se trata de la represión inicial efectuada por los vencedores en Triana o de las ejecuciones ejemplarizantes, como las de los mineros de Huelva, llevadas a cabo en las semanas posteriores? En todo caso se trata de un impresionante testimonio gráfico debido a Serrano.

\section{LA GUERRA CIVIL EN HUELVA}

Francisco Espinosa Maestre. 1996

do tergiversadas y siempre con el mismo objetivo: endosar a unos, las víctimas del golpe militar, lo que era responsabilidad de otros, los golpistas.

\footnotetext{
La crueldad fue una constante en las milicias del Frente Popular, durante el tiempo que dominaron pueblos de las provincias de Sevilla, Huelva, Córdoba y Badajoz. Los muertos apilados en las calles, los cuerpos bárbaramente mutilados y quemados, las fosas comunes sin cerrar... El Gobierno de Madrid decía que estas fotografías eran hábiles montajes gráficos. $(370,371$ y 372).
}

SEVILLA FUE LA CLAVE

Nicolás Salas. 1992

El paso siguiente fue descubrir algo que ya debiera haber sabido: la foto aparecía en el Avance del Informe Oficial sobre los asesinatos, violaciones, incendios y demás depredaciones y violencias cometidos en algunos pueblos del Mediodía de España por las hordas marxistas al servicio del llamado Gobierno de Madrid. Julio y agosto de MCMXXXVI (Sevilla). La elaboración de este folleto, el primero de una serie 
que sería el origen de la Causa General, había sido ordenada por Luis Bolín, uno de los jefes de propaganda al servicio de Queipo, en la temprana fecha de 24 de agosto de 1936. La razón era simple: había que contrarrestar los efectos de la matanza de Badajoz, ocurrida diez días antes y que estaba conmocionando a la opinión pública europea. Este primer Avance, que debió aparecer en octubre de 1936, estaba dedicado casi íntegramente a pueblos de Andalucía occidental, y en el anexo fotográfico, bajo la mencionada fotografía, se leía: "Cadáveres de personas de orden, asesinados (sic) en Talavera de la Reina por la hordas rojas». Pese a la mentira de fondo al menos se mencionaba una localidad.



Cadaveres de personas de orden, asesinados en Talavera de la Reina por las hordas as rojat

AVANCE DEL INFORME OFICIAL

Junta de Defensa Nacional de Burgos. 1936

Esta línea de estilo goebbeliano iniciada por Bolín en 1936 y continuada por Salas en 1992 había sido rota sin embargo por Fernando Díaz Plaja en 1972 en el segundo tomo de La España política del siglo XX (Plaza\&Janés, Barcelona, 1972). Allí se reproducía de nuevo la foto junto al siguiente texto: "Caídos en Talavera de la Reina tras la toma de la ciudad por los nacionales». Pese a la ambigüedad y a las obvias reminiscencias falangistas de la palabra caídos o del carácter profranquista que implicaba seguir llamando nacionales a los sublevados, al menos se daba a entender que esos cadáveres eran consecuencia de la toma -no eran ya tiempos para seguir hablando de liberación- de Talavera. Todo un avance para la época.

Fue entonces, en el verano de 2002, cuando, viendo la posibilidad de poner la fotografía en la portada de La columna de la muerte, planteé la cuestión a Fernando Magán, buen conocedor de lo ocurrido en Talavera, quien me informó -yo no me había dado cuenta pese a conocer el libro- de que la fotografía había aparecido también en la página 239 de Prisión y muerte en la España de posguerra, de José Manuel Sabín (Muchnik, 1996). En lo que debió ser un cartel antifascista 


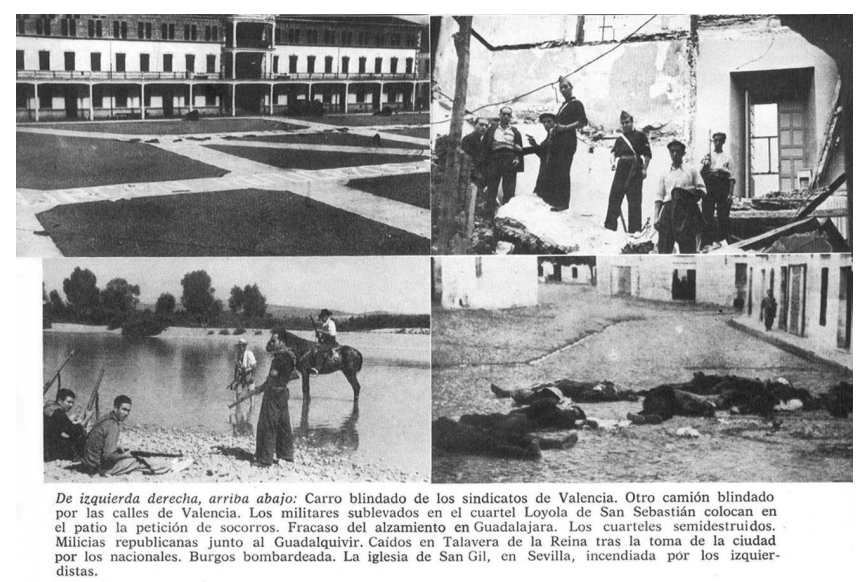

LA ESPAÑA POLÍTICA DEL SIGLO XX, en fotografías e imágenes Fernando Díaz-Plaja 1972

en el que destacaba la palabra ; VENGANZA! se veían la foto de Talavera, reducida en la parte superior, y -ocupando casi todo el cartel- otra muy conocida (ubicada en ocasiones en Badajoz) que muestra una hilera de cadáveres junto a un muro. El pie de foto, que reproducía el texto que en letra pequeña se veía en medio del cartel, decía acertadamente: "Obreros fusilados en masa por las tropas fascistas en Navalcarmero y en Talavera de la Reina».

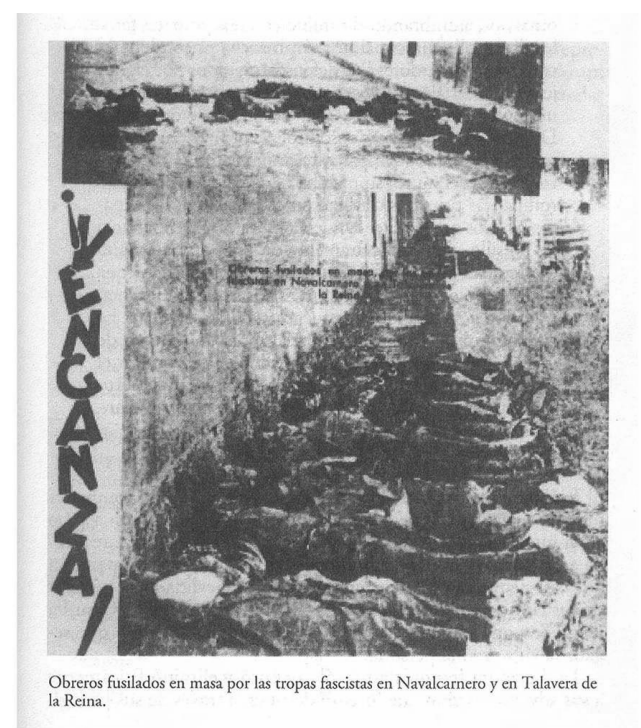

PRISIÓN Y MUERTE, en la España de postguerra José Manuel Sabín. 1996 
Pero Fernando Magán no sólo me informó de lo ocurrido en Talavera el día 3 de septiembre de 1936, sino que me habló de la existencia de un testigo de aquella masacre. ${ }^{3}$ Fue así como a comienzos de agosto de 2002 pude hablar por teléfono con Miguel Navazo Taboada, quien me envió su testimonio por escrito y el fragmento de sus memorias inéditas que se refería a este hecho. Sobre la fotografía relataba:

Al frente se ve un portalón grande; eso era una posada llamada "Del León» y otra puerta pequeña que fue entonces una peluquería. En la parte izquierda existía entonces otra posada que llamábamos del señor Pedro; en dicha posada estaban en aquel momento seis u ocho segadores gallegos que habían venido a segar, como hacían todos los años. Aquellos segadores fueron sacados de la posada y fusilados igualmente que el resto de los prisioneros.

Y en sus memorias se leía:

Así transcurrían las horas lentas en los sótanos. Un día, al sentir revuelo en la calle con voces que gritaban vivas a España, salimos fuera. Lo primero que vi en la plaza fue a tres personas que iban custodiadas por varios moros armados con fusiles. Uno de aquellos desgraciados echó a correr hacia la calle de Carnicerías y los moros seguidamente comenzaron a dispararle. El hombre se refugió debajo de un automóvil y allí mismo lo remataron a tiros.

Para mí aquello fue un horror tremendo, pero lo peor estaba por venir. Ya casi llegaba a la puerta de mi casa, cuando vi bajar por la calle de Carnicerías hacia el río a un montón de hombres con monos azules unos, y otros con camisas, que iban atados con sogas. A su alrededor, muchos moros, legionarios y otros soldados con gorros colorados que luego supe que se llamaban regulares. Yo me quedé paralizado, aterrorizado, indeciso, sin saber qué hacer, y cuando llegaba a la puerta de mi casa e iba a entrar, aquella puerta se cerró ante mí. Mi madre y los vecinos que vivían arriba pensaban que yo estaba dentro. Allí me quedé, en el rincón de la puerta, viendo aquel panorama, oyendo los gritos de los moros, que en plan de vencedores provocaban y maltrataban a las personas que custodiaban, a las que llevaban atadas. De repente algo pasó; supongo que alguno de aquellos infelices intentaría desatarse y emprender la huida, o simplemente la furia desatada de esa tropa de bárbaros. El caso es que comenzó el mayor de los horrores. Los militares comenzaron a fusilar a diestro y siniestro enloquecidos de fuego y de sangre. Me refugié en el rincón de la puerta de mi casa y allí aguanté todo aquel horror, mirando toda la barbarie de la que puede ser capaz la especie humana hasta que un militar con estrellas se acercó a mí y me dijo: jMuchacho! iqué haces aquí? Yo recuerdo que le dije con voz entrecortada y vacilante: Es que vivo en esta casa y se ha cerrado la puerta. El militar dijo: jJoder! Te han podido matar los moros. Ven conmigo. Y me metió en una posada que había frente de la casa, que tenía la puerta abierta. Allí estuve hasta que el mismo militar volvió a recogerme diciendo: Muchacho, tápate los ojos con este pañuelo y ven conmigo, que la

3. De ello tuvo noticia el verano de 2002 el investigador afincado en Talavera Benito Díaz Díaz, quien, sin citar que existía una investigación en curso ni la procedencia de la información que recibió y aprovechó de unos y otros, publicó un tan oportunista como superficial artículo sobre la fotografía en una revista de Talavera con el título "Republicanos fusilados en la calle Carnicerías (Talavera de la Reina, 3 de septiembre de 1936): manipulación franquista de la Historia» (Cuaderna, 185, $4^{\circ}$ trim. 2002). 
puerta de tu casa ya la han abierto. (...). Mi madre me estaba esperando ansiosa por abrazarme y aterrorizada con lo que tenía ante su vista.

Aquellos muertos permanecieron en la calle más de tres días. Los retiraron los carros que se empleaban en la recogida de basuras. Eso hizo que durante mucho tiempo -quizás varios años-, cuando llovía, la sangre manaba de entre las piedras, pareciendo que todo acababa de suceder, porque el suelo estaba empedrado y la tierra había absorbido la sangre. Tal era nuestro miedo que debajo de una de las ventanas de mi casa estuvo adherido a la pared un trozo de cráneo con su pelo correspondiente. Nadie se atrevía a quitarlo de allí.

Fue una noche terrible aquella del tres de septiembre. Continuamente estuvimos oyendo disparos que nosotros atribuimos a lo que se llamaban tiros de gracia. Y los gritos de agonía de los moribundos llamando a sus seres queridos. Fue tremendo. Ahora pienso que le debo la vida a aquel militar desconocido, pues si no hubiera sido por él seguramente los moros y legionarios, enloquecidos en su orgía de sangre, me habrían matado.

Leído esto era posible por fin poner a la foto, muestra ejemplar de lo que fue la columna de la muerte, su verdadero pie:



1. Foto de la cubierta: Talavera del Tajo, 3 de septiembre de 1936. Masacre en la calle Carnicerías tras la entrada de las fuerzas de Yagüe (Hemeroteca Municipal de Sevilla, Fondo Serrano).

LA COLUMNA DE LA MUERTE

Francisco Espinosa Maestre. 2003

Ahora quedaba convertirla en portada. Conseguir que la editorial Crítica lo aceptara no fue difícil. Además, teniendo como antecedente el fallo de la portada de Morir, matar, sobrevivir (Crítica, Barcelona, 2002), todo resultaba más fácil. En aquella ocasión se decidió poner en portada una conocida fotografía del archivo de Roger-Violet que reproduce supuestamente el fusilamiento de un derechista. Había dos problemas: la foto parece un montaje y, en todo caso, el fusilamiento de un derechista no parecía la foto idónea para aquel libro sobre la 



represión franquista. ${ }^{4}$ En La columna de la muerte había, además, otro elemento a favor de que la foto de Serrano ocupase la portada: la existencia de un anexo, el VII, dedicado exclusivamente a contar su historia, que resultó definitivo a la hora de aceptar la foto en la cubierta.

Una vez publicado el libro me llegó información de otros lugares donde había aparecido la fotografía. Así, a través de Miguel Ángel Lama, puede hacerme de una copia de la revista católica francesa titulada L'Espagne sanglante, de 1937, en la que además de situarla en Talavera la Real (Badajoz) se leía que se trataba de "los campesinos de la aldea masacrados por los comunistas». También supe por un lector que aparecía en otra revista francesa, L'Illustration, de octubre de 1936, con un increíble pie de foto en el que se responsabilizaba del crimen a los gubernamentales, antes de abandonar Talaveira de la Reina, y donde la autoría de la foto se adjudicaba a F. de Poncins. Fue así como circuló por una Europa en la que los enemigos de la República, especialmente los círculos católicos favorables al golpe militar, supieron imponer su propaganda. De modo que mientras las imágenes tomadas por René Brut de la matanza de Badajoz eran

4. Según Santiago Perinat la foto apareció por primera vez en la revista $V u$ (París) en mayo de 1937 sin autor ni agencia y con el texto: «Sous les balles des soldats de la Généralité: l'espion mourra fusillé! Cet homme qui avec dignité, fait face a la mort, est-il vraiment un membre de la fameuse 5e colonne, (...)». Perinat, que mantiene que foto es ficticia por diversos motivos, considera no obstante que denuncia la severidad de la justicia de Companys (véase PERINAT, S., "Foto apòcrifa i sospitosa", L'Avenç, n² 296, nov. 2004, p. 14). 
neutralizadas, otras, las de los escasos lugares del sur donde hubo terror rojo, eran exhibidas y circulaban sin cortapisa alguna, entre ellas, y dada la escasez de muestras, algunas como la de Talavera.


L'ESPAGNE SANGLANTE

Talavera la Real:

Los campesinos de la aldea, masacrados por los comunistas 




La última aparición de la foto de la que tengo noticia pertenece al terreno de lo que se entiende por reincidencia contumaz. Se trata del ya mencionado Nicolás Salas, quien no contento con lo dicho en 1992 nos ha vuelto a contar ahora, en ese inenarrable compendio chapucero de manipulación y falsedad titulado La otra memoria histórica (Almuzara, Sevilla, 2006) que se trata de una muestra de la "barbarie marxista», si bien en esta ocasión, a saber por qué, ha decidido situar el hecho en Montoro (Córdoba).

Falta ver -una vez más gracias a la amabilidad de Fernando Magán- qué queda del escenario de la fotografía en la actualidad. El fondo ha desaparecido y de la calle sólo queda prácticamente en pie la casa de Miguel Navazo. O sea, casi nada.

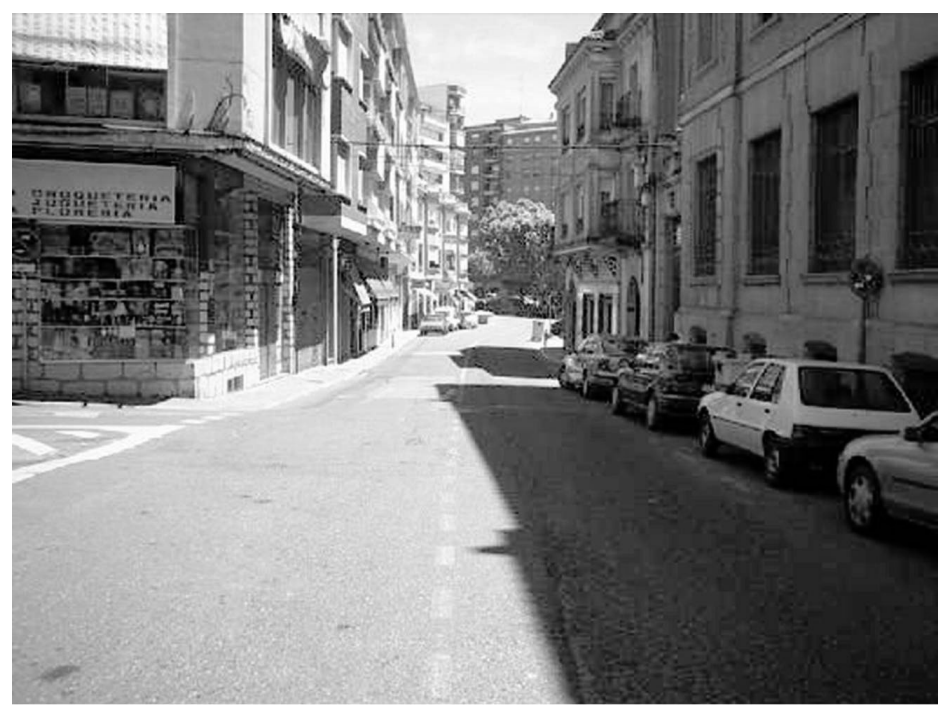

Vista de la Calle Carnicerías en la actualidad 
Lo que con tanta fuerza narró Miguel Navazo sucedió a media tarde, unas horas después de la entrada de los golpistas en Talavera. Según parece la fotografía recoge sólo una parte de la matanza. Cuando hablé con él le dije que esa terrible escena que presenció en Talavera se había repetido en cada ciudad y en cada pueblo desde que las columnas iniciaron su recorrido y que, precisamente por eso, aunque no correspondiese a ninguno de los pueblos tratados, pensaba que debía aparecer en la portada de mi libro como testimonio excepcional y fidedigno de lo que fue el golpe militar en las primeras semanas. Finalmente, recordando mi antigua duda sobre si no serían esos cadáveres los de los mineros onubenses, caí en la cuenta de que entre la matanza de los mineros onubenses en Sevilla y la masacre de Talavera sólo habían existido tres días de diferencia. La escena, sin duda, debió ser muy parecida.

Quedaba el interrogante de por qué Serrano tomó aquella fotografía. Sólo hay una explicación. Como la fotografía pasó a engrosar el fondo gráfico de atrocidades cometidas por las hordas marxistas, es posible que Serrano -que no en vano recibió la Cruz de Campaña por el trabajo periodístico realizado con las columnas que se dirigían a Madrid- la tomara precisamente para que el gabinete de propaganda de Queipo hiciera con ella lo que considerara conveniente, pues como nos contó Antonio Bahamonde en sus memorias: «Sacan fotografías de los cadáveres de fusilados... para exhibirlas en España y en el extranjero, diciendo que son crímenes feroces cometidos por los rojos». Así, el Avance que contenía la foto fue traducido a los principales idiomas y circuló ampliamente por el mundo propagando la mentira hasta hoy mismo.

En 2003, cuando escribí el texto del anexo, dije que creía que, a partir de ahora, después de 64 años, nadie que buscara la verdad podría decir que esos cadáveres pertenecían a personas de orden asesinadas por las hordas rojas o seguir mostrando la fotografía como prueba de la crueldad de las milicias del Frente Popular. Intentaba yo cerrar el asunto diciendo: «Se trataba simplemente de vecinos -entre ellos varios segadores gallegos- de la aún denominada Talavera del Tajo, asesinados en la calle Carnicerías durante la tarde del 3 de septiembre de 1936 por fuerzas militares golpistas al mando del teniente coronel Juan Yagüe Blanco». Vana esperanza. El caso de la otra memoria -no sé si será otra pero desde luego se parece tanto a la de siempre que prácticamente es la misma-de Nicolás Salas muestra que para los goebbelianos lo único que cuenta es el objetivo final y que el fin justifica los medios. Ya decía yo: "nadie que buscara la verdad...».

La historia de de esta fotografía constituye un paradigma de lo ocurrido con todo lo que nos legó el franquismo. Necesitaríamos hacer una operación similar con otras muchas cosas que pasan por lo que no fueron. De ahí las tremendas dificultades para afrontar ese pasado y para ponernos de acuerdo sobre él. ¿Acaso sería posible llegar a un acuerdo sobre lo que representa esta fotografía sin la cadena de hechos que van de las primeras indagaciones en la Hemeroteca Municipal de Sevilla en los primeros noventa a la aparición de Miguel Navazo en el 2002? 


\section{Epílogo alicantino}

Cuando en el verano de 2006 expuse en Alicante la historia la fotografía, entregué a los asistentes como complemento una viñeta de Quino sobre la que me había hecho fijar mi atención mi amiga María Oliver. Más oportuna no podía ser. Con ella debe cerrarse (por ahora) este itinerario de setenta años en la vida (1936-2006) de una fotografía.



BOCROWOLM SOIDADO DEL EJERCITO QUE APOYA ALDEMOCRÁTICO PRESIDENTE MAZEVICL REGALA. CHOCO ATE A UNA MADRE V SU HIJTA ENTTR LAS RUINAS DE SU CAGA DESTRLITA DOR GLERRIILROG.

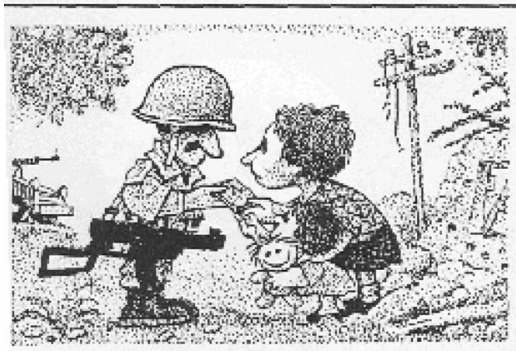

MAH LLIPARA CGEBRARELDA DE EJEXTO LASMUTRES DESST PLOUENO PAB SIOUEN LA ANTIGUA TRAOICIOT

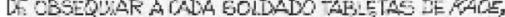
IN TIPICOJILE ELASCRADO CDN SEMLILAS DE RA'

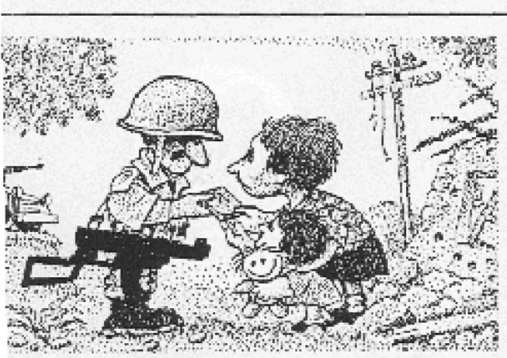

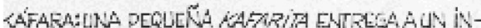


1OW WA DE AERADECIWIFNTO WOR HAEER DAOOMUERTE



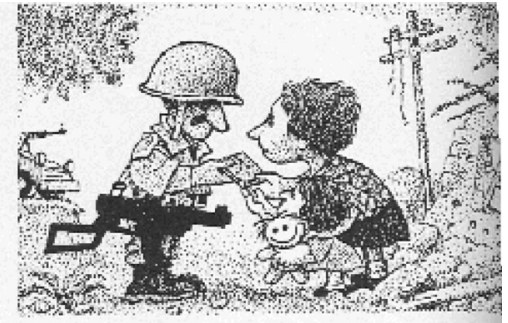


NARCOTICOE CONTROLA LOS DOCLWENTOSDE LIVA CAMPESNA. WICHASTEE ASUTLLZANA SISH JOS DARA PASAE DROEL OCULTA FN SUS TJGUEI LS

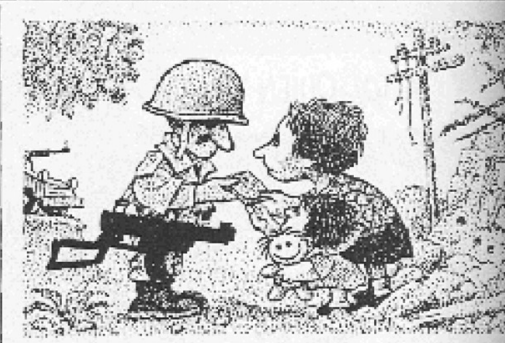



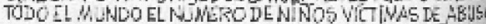



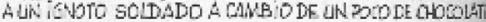




RLCALA CNOOOLAIF A UNA MORE Y SU HIJITA EU TRE LAS RUINAE DE SL CASA DESTRUIDA POR -

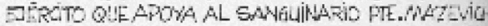

Quino, Esto no es todo, Barcelona, Editorial Lumen, 2001. p. 396. 